\title{
WYBRANE PROBLEMY ROLNICTWA ŚWIATOWEGO
}

\begin{abstract}
Abstrakt
Przed rolnictwem światowym stoi poważne wyzwanie, jak zapewnić rosnacej liczbie ludności, prawdopodobnie też przeciętnie bogacacej się, odpowiedni standard ilościowy $i$ zdrowotny wyżywienia, obniżając - a przynajmniej nie zwiększając - presję na środowisko przyrodnicze i zmiane klimatu. Będzie rosła zatem konkurencja o zasoby ziemi, wody, surowców energetycznych i mineralnych niezbędnych do wytwarzania nawozów potasowych ifosforowych.

Istnieje jednak kilka strategii sprostania powyższym wyzwaniom. Potrzebne sa skoordynowane i konsekwentne działania zarówno po stronie popytu (zmiany diety $i$ wzorców konsumpcyjnych oraz redukcje strat), jak i podaży na rynkach rolno-żywnościowych. W szczególności trzeba starać się zamknać istniejace obecnie luki produktywności, poprawić efektywność zastosowania wszystkich zasobów, inwestować $w$ badania $i$ wdrożenia rolnicze, zmniejszyć straty w całych łańcuchach żywnościowych. Pojedyncze działania powinno się podejmować przy tym równocześnie, $i$ to na skale globalna, co samo w sobie stwarza ogromny problem.

Od razu nasuwa się tu refleksja zwiazana z negocjacjami klimatycznymi. Niemal wszyscy zgadzają sie, że przyjmujac wielostronne porozumienie, łaczny dobrobyt uległby maksymalizacji. Jednak pokusa ,jazdy na gape”” przeważa wśród wielu krajów, bo wciąż priorytety mają cele i efekty krótkookresowe oraz interesy narodowe.
\end{abstract}

Słowa kluczowe: rolnictwo światowe, zmiana klimatu, bezpieczna przestrzeń operacyjna, bezpieczeństwo żywnościowe, popyt rolno-żywnościowy, elastyczność cenowa, modele CGE i PE, zmiana diety, zrównoważona intensyfikacja 


\section{Wprowadzenie}

Współczesny świat, wielorako i wielopoziomowo współzależny, stoi przed wieloma wyzwaniami, sprostanie którym wymaga podejmowania już dziś skoordynowanych w skali globalnej decyzji, działań, zarządzania, regulacji i koordynacji, tworzenia adekwatnych instytucji oraz innowacyjnego finansowania. Nie pretendując do kompletności zestawu tych wyzwań, warto wskazać, iż presja demograficzna, zmiany diety i wzorców konsumpcji, cały kompleks problemów związanych ze zmianą klimatu i zużyciem energii oraz emisją gazów cieplarnianych, a z drugiej strony wciąż kruchy wzrost gospodarczy, nadal rosnące zadłużenie publiczne, widoczna presja deflacyjna, pogłębianie się zróżnicowania dochodowego i majątkowego, rozczarowanie globalizacją i pewna fragmentacja handlu światowego oraz powrót geopolityki i Realpolityki to niezbyt sprzyjające otoczenia dla rolnictwa i sektora żywnościowego.

Rolnictwo z kolei musi sprostać wzrostowi popytu na jego wytwory, ale znacznie szerzej rozumiane niż czyni się to w podejściu tradycyjnym. Chodzi bowiem o to, że sektor ten ewoluuje w kierunku składnika biogospodarki/bioekonomii, a więc integruje się z sektorem biotechnologicznym, energetycznym, wydobycia surowców mineralnych i przemysłem farmaceutycznym (Swinnen J., Riera O., 2013; Zilberman D., 2013). Powinno się to odbywać oczywiście w sposób zrównoważony, czyli nieszkodzący środowisku przyrodniczemu, bioróżnorodności i dostarczaniu dóbr publicznych, niepogłębiający zmiany klimatu, przeciwdziałający biedzie i ubóstwu, dbający o bezpieczeństwo i dobrostan konsumentów. Wobec wyczerpywania się wolnych zasobów ziemi nadających się do użytkowania rolniczego prawdopodobnie potrzebna będzie druga zielona rewolucja, oparta głównie o zaawansowaną biologię molekularną i teoretyczną wspieraną przez bioinformatykę oraz modelowanie matematyczne, a więc ogólnie o genomikę oraz biotechnologię. Niezbędne będą zatem odpowiednie nakłady finansowe, publiczne i prywatne, w sferze rolniczych badań i wdrożeń, ale też regulacje, by właściwie internalizować nowe typy efektów zewnętrznych.

Artykuł ma cechy studium przeglądowego. Jego podstawowym celem jest identyfikacja wybranych problemów, z którymi konfrontowane będzie w najbliższych dekadach światowe rolnictwo, oraz zarys możliwości ich przynajmniej złagodzenia. W pierwszej części przedstawiono ogólne wyzwania stojące przed sektorem rolnym, następnie scharakteryzowano determinanty popytu rolno-żywnościowego i pozostałego. W dalszej części przybliżono kwestię podaży generowanej przez rolnictwo i dokonano przeglądu opcji strategicznych sprostania wyzwaniom.

\section{Usytuowanie analizy}

W tabeli 1 zestawiono wybrane charakterystyki rolnictwa światowego na przełomie poprzedniej i obecnej dekady XXI wieku. Wynika z niej m.in., że rolnictwo to wykazuje różnego typu nierównowagi. Można przypuszczać, że w przyszłości mogą się one nasilać w miarę zwiększania się liczby ludności, zaostrzy 
się konkurencja o zasoby odnawialne i nieodnawialne, postępować będzie zmiana klimatu i degradacja środowiska przyrodniczego. Te globalne problemy wymagają odpowiedzi również na poziomie globalnym, a więc odpowiednio skonstruowanej, wdrażanej, finansowanej, monitorowanej i korygowanej polityki. Jej zarys w ujęciu systemu dynamicznego przedstawiono na rysunku 1.

\section{Wybrane charakterystyki światowego rolnictwa}

Tabela 1

\begin{tabular}{lc}
\hline \multicolumn{1}{c}{ Wyszczególnienie } & Wartość \\
\hline Liczba mieszkańców Ziemi (mld) & 7,0 \\
Liczba osób niedożywionych (mld) & 0,9 \\
Liczba osób otyłych i z nadwagą (mld) & 1,5 \\
Liczba ludzi żyjących za mniej niż 0,25 USD dziennie (mld) & 1,4 \\
Liczba ludzi żyjących na suchych obszarach (mld) & 2,0 \\
Liczba ludzi zależnych od zdegradowanych gleb (mld) & 1,5 \\
Liczba osób pracujących w rolnictwie (mld) & 2,6 \\
Straty spowodowane przez zmiany klimatu (mld USD) & 11,4 \\
Powierzchnia użytków rolnych (mld ha) & 4,9 \\
Powierzchnia związana z produkcją zwierzęcą (mld ha) & 3,7 \\
Średnioroczny wzrost produkcji rolniczej w latach 1997-2007 (w \%) & 2,2 \\
Roczne straty żywności (mld ton) & 1,3
\end{tabular}

Źródło: Beddington J.: Achieving food security in the face of climate change. Final report from the Commission on Sustainable Agriculture and Climate Change, CGAR, Denmark 2012.

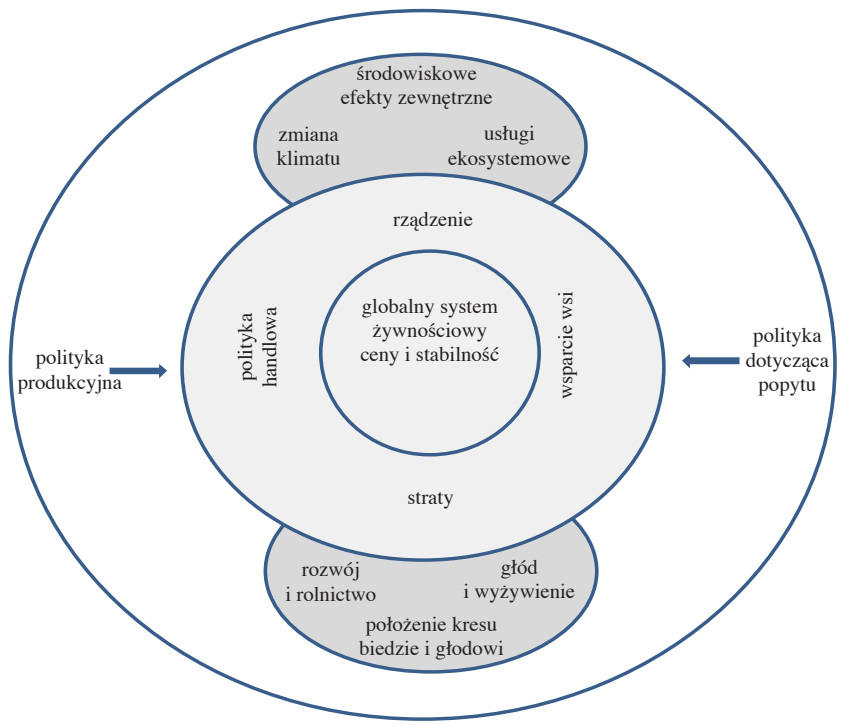

Rys. 1. Istota globalnej polityki żywnościowej

Źródło: Opracowanie własne na podstawie: Godfray J.Ch.H., Garnet T.: Food security and sustainable intensification, Philosophical Transactions of the Royal Society B, nr 369, 2014. 
Mamy tu do czynienia z elementami współzależnymi, dynamicznymi, jednocześnie osadzonymi w otoczeniu i podlegającymi jego wpływom, ale też zwrotnie na nie oddziaływującym. W centrum polityki jest cel żywnościowy, ale można go osiągać różnymi drogami, strategiami. Jednak najlepszym, wręcz koniecznym rozwiązaniem jest działanie zorientowane równocześnie na kilka obszarów. Samo w sobie jest to już niezmiernie trudne do konceptualizacji i ewentualnej optymalizacji. Do tego dochodzą różnice w celach, priorytetach i wartościach głównych graczy globalnych. Dochodzenie do konsensusu jest zatem procesem ewolucyjnym, bardzo złożonym, w którym okresy współdziałania i ogólnoświatowej koordynacji przeplatać się będą z nawrotami protekcjonizmu i fragmentacją handlu oraz globalnego systemu ekonomicznego. Mimo to warto próbować szukać obszarów kooperacji. W tym kontekście bardzo interesująca jest koncepcja tworzenia tzw. bezpiecznej przestrzeni operacyjnej dla całej ludzkości (ang. the safe operating space). Istotę ww. bezpiecznej przestrzeni oddaje lewa strona rysunku 2, natomiast z prawej jego strony pokazano strategie cząstkowe znalezienia się w niej lub jej powiększenia. Liniami przerywanymi oznaczono stan wyjściowy, liniami ciągłymi natomiast stan końcowy po przeprowadzeniu działań, które opisują odpowiednio skierowane strzałki. W ujęciu wysoce stylizowanym ww. przestrzeń to obszar wspólny ograniczony liniami oznaczającymi zmiany klimatu, maksymalne możliwości produkcji żywności i popytu na nią. Obecnie rolnictwo światowe znajduje się poza tą przestrzenią (ciemna kropka w lewej części rysunku 2). Żeby natomiast móc się w niej znaleźć, potrzebne są równoczesne działania w obszarze zmiany diety i redukcji strat surowców rolnych i żywności, zmniejszenia emisji gazów cieplarnianych, opracowania i wdrożenia technologii zorientowanych na poprawę efektywności i produktywności rolnictwa oraz całego łańcucha żywnościowego. Postęp w tej dziedzinie automatycznie przekładałby się również na ograniczenie do minimum ekspansji powierzchniowej rolnictwa i poziomu jego niezrównoważonej intensywności. Jak z powyższego wynika, słowo „bezpieczne” oznacza, iż teoretycznie możliwe jest uzyskanie odpowiedniego bezpieczeństwa żywnościowego dla społeczności światowej bez przekraczania granic biofizycznych wyznaczanych przez środowisko przyrodnicze naszej planety. Dla porządku dodajmy jeszcze, że bezpieczna przestrzeń może być powiększona, gdy wzrośnie światowy potencjał generowania większej podaży produktów rolno-żywnościowych (przesunie się w górę krzywa maksymalnej produkcji na rysunku 2). 


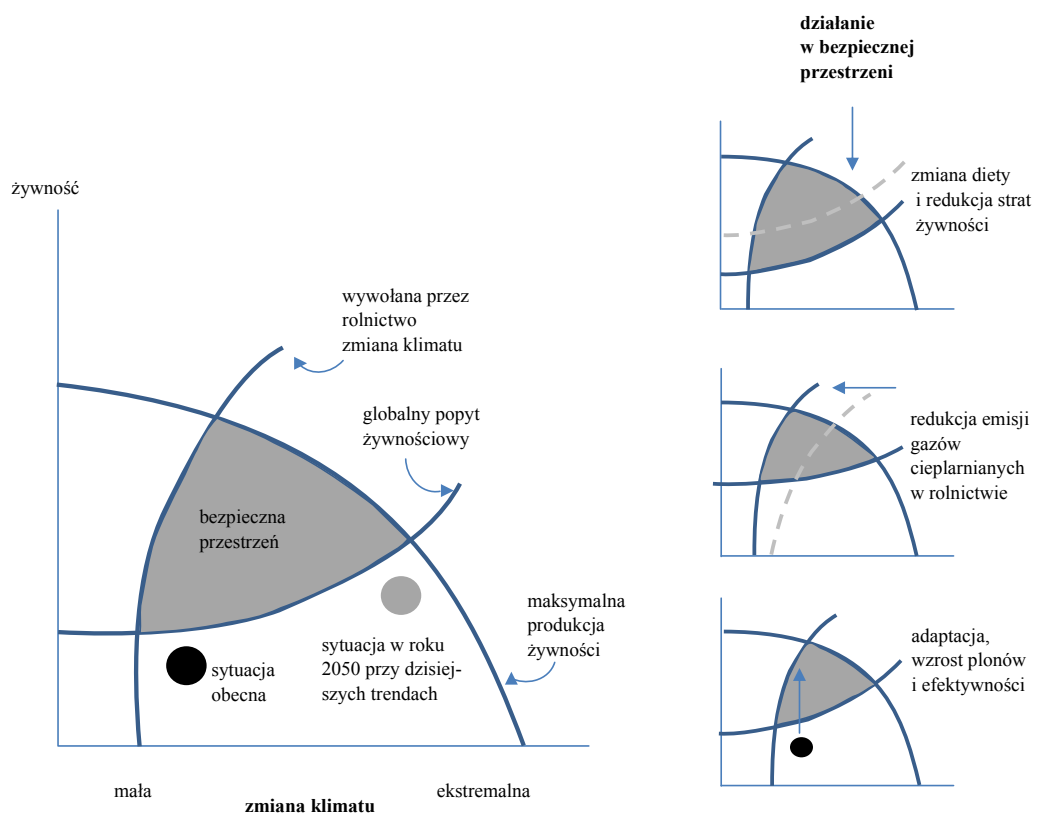

Rys. 2. Bezpieczna przestrzeń operacyjna we wzajemnie powiązanych systemach żywnościowym i klimatycznym

Źródło: Opracowanie własne na podstawie: Beddington J.: Achieving food security in the face of climate change. Final report from the Commission on Sustainable Agriculture and Climate Change. CGAR, Denmark 2012.

\section{Determinanty popytu rolno-żywnościowego}

Popyt na pojedynczy produkt rolno-żywnościowy wynika z jego ceny, ceny innych produktów znajdujących się w obszarze zainteresowań reprezentatywnego gospodarstwa domowego, jego dochodu oraz struktury potrzeb i preferencji (Koester U., 2010). W przypadku natomiast popytu zagregowanego kapitalną rolę odgrywa tempo zmian ludności oraz PKB i urbanizacji. Do niedawna przyjmowano, iż naszą planetę $\mathrm{w}$ połowie bieżącego stulecia zamieszkiwać będzie 9,2-9,3 mld ludzi. Później miał się rozpocząć spadek populacji. Obecnie coraz częściej prognozuje się, że presja demograficzna trwać będzie do końca XXI wieku, a liczba mieszkańców globu osiągnie nawet 12-13 mld. Powszechnie też zakładano, że dochody per capita będą rosły, dwukrotnie więcej do 2050 roku w stosunku do roku 2010 (von Lampe M. et al., 2014; Lotze-Campen H. et al., 2008). Obecnie nie jest to już także pewne, natomiast postępować będzie urbanizacja. Ocenia się, że już w roku 2007 połowa ludzi mieszkała w miastach, w roku 2025 wskaźnik ten ma wzrosnąć do ok. 56\%, a w roku 2050 może przekroczyć nawet $75 \%$. Miasta będą coraz więcej zatem wytwarzać PKB, ale też 
emitować więcej szkodliwych zanieczyszczeń. W związku z tym na znaczeniu zaczyna zyskiwać koncepcja „prężności miejskiej” (ang. a urban resiliance), a więc - w dużym skrócie - zrównoważonego ich wzrostu oraz rozwoju.

Wyższe dochody per capita oraz przenoszenie się mieszkańców wsi do miast już w przeszłości wywierały poważne zmiany w strukturze diety oraz ilości spożywanej żywności. Główne tendencje w tym zakresie zaprezentowano na rysunku 3.

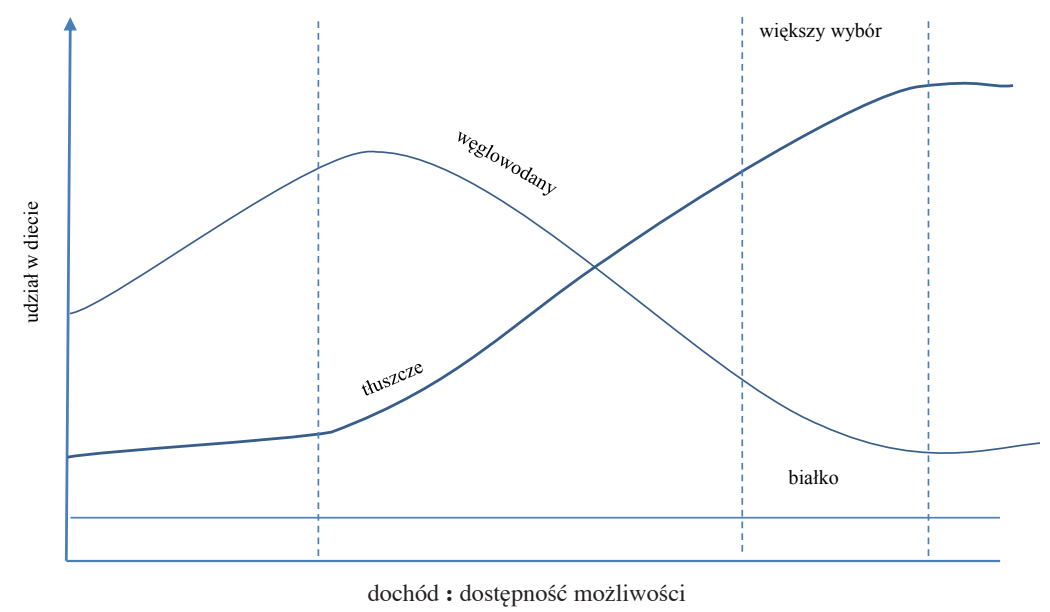

Rys. 3. Zależności między dietą a dochodami

Źródło: Opracowanie własne na podstawie: Beddington J., Achieving food security in the face of climate change. Final report from the Commission on Sustainable Agriculture and Climate Change, CGAR, Denmark 2012.

Jak widać, generalnie malała konsumpcja zbóż i warzyw, a rosła cukru, tłuszczów i produktów zwierzęcych. W sumie jednak ilość spożywanego białka była względnie stabilna, chociaż pochodziło ono w coraz większym stopniu z produktów zwierzęcych. Konsumpcja tłuszczu rosła natomiast nawet przy wysokich dochodach per capita, ale cukry złożone w coraz większym zakresie zastępowane były cukrami prostymi. Z kolei spożycie węglowodanów przeciętnie malało już przy relatywnie umiarkowanych dochodach per capita (Beddington J., 2012; Godfray J.Ch.H. et al., 2010; Godfray J.Ch.H. et al., 2014; Smith P., 2013). Zmiany te mają poważne następstwa zdrowotne (stymulują wzrost odsetka ludzi otyłych i z nadwagą oraz związane z tym choroby), wpływają także na technologię i systemy wytwarzania w rolnictwie oraz intensywność gospodarowania w tym sektorze. Poważne zmiany dokonują się również w przemyśle spożywczym, w którym wzrasta znaczenie głębokiego przetwórstwa. W konsekwencji mamy bardzo niebezpieczną kombinację: wciąż wielu mieszańców globu cierpi głód, ale równocześnie najbiedniejsi są najbardziej 
dotykani przez negatywne następstwa zdrowotne zmian zwyczajów żywieniowych. Niestety, ekonomiści nadal bardzo różnią się w ocenie przyszłego popytu rolno-żywnościowego. Dotyczy to zarówno modeli równowagi ogólnej, jak i cząstkowej, w których odczuwa się przede wszystkim dotkliwy niedobór wiarygodnych oszacowań elastyczności cenowych i dochodowych popytu ${ }^{1}$.

Przyszły globalny popyt rolno-żywnościowy może być modelowany za pomocą modeli CGE (ang. computable general equilibrium) oraz równowagi cząstkowej PE (ang. partial equilibrium). Problemy z tym związane zostaną przedstawione przez odwołanie się do analizy porównawczej 6 modeli CGE oraz 4 PE, wykonanej przez H. Valina et al. (Valin H. et al., 2014). Badaniem objęto 13 regionów świata oraz główne produkty roślinne i zwierzęce, a modelowanymi latami były: rok 2005 i 2050. Jako jednostkę miary przyszłego popytu przyjęto kcal per capita i dzień oraz jednostki pieniężne.

Modele PE przeważnie popyt opisują dosyć prosto, za pomocą funkcji zredukowanych, mają nieograniczony stopień swobody, ale ujmują z reguły wąski zakres przede wszystkim surowców rolniczych wyrażonych w jednostkach ilościowych (fizycznych), posługują się nadwyżką konsumenta w formie ilości przyjmowanych kalorii jako indeksem mierzącym dobrobyt gospodarstw domowych ${ }^{2}$. Z kolei modele CGE wyprowadzone zostały z rachunków nakładów - produktów. System popytu opisany jest w nich w konwencji użyteczności. Ograniczenia tych modeli wynikają z przyjętej funkcji popytu, koncentrują się bowiem na konsumpcji finalnej dóbr, których z reguły jest mniej, ale szczegółowo ujętych wzdłuż całego łańcucha żywnościowego. Konsumpcja mierzona jest w nich $\mathrm{w}$ jednostkach pieniężnych, a dobrobyt reprezentatywnego gospodarstwa domowego szacowany za pomocą ekwiwalentnej lub kompensacyjnej wariancji użyteczności.

W standardowym podejściu w modelach PE popyt żywnościowy per capita wyrażany jest poniższą formułą:

$$
D_{r, c, t}=\operatorname{Pop}_{r, t}\left(\frac{Y_{r, t}}{\operatorname{Pop}_{r, t}}\right)^{\eta_{r, c, t}} \prod_{c^{\prime}}\left(P_{r, c^{\prime}, t}\right)^{\varepsilon_{r, c, c^{\prime}, t}}
$$

\footnotetext{
${ }^{1}$ Trzeba mieć jednak świadomość, że współcześnie w analizach popytu na produkty rolno-żywnościowe oraz ich podaży coraz częściej badacze odwołują się do koncepcji zrównoważonej diety. Według FAO, jest to pojęcie, które próbuje zintegrować bezpieczeństwo żywnościowe i żywieniowe, kwestie bioróżnorodności, środowiskowe i klimatyczne, sprawiedliwego handlu, a nawet dziedzictwa kulturowego i tradycji kulinarnych (Kwasek M., Obiedzińska A., 2014). Zdecydowanie się na tak szeroką koncepcję jeszcze bardziej utrudni modelowanie popytu i podaży produktów rolno-żywnościowych.

${ }^{2}$ Tak zdefiniowana nadwyżka konsumenta zdecydowanie różni się od jej rozumienia w ekonomii, w której ujmuje się ją jako dodatkową korzyść nabywcy danego dobra ponad kwotę poniesionych na ten cel wydatków. Niekiedy w ekonomii środowiskowej spotyka się także niestandardowe definiowanie powyższej nadwyżki.
} 
gdzie:

$D_{r, c, t} \quad-$ popyt żywnościowy na dobro $c$, w regionie $r$ i roku $t$,

Pop - liczba ludności,

$Y \quad-$ dochód całkowity,

$P \quad-$ wektor cen produktów,

$\eta \quad-$ elastyczność dochodowa popytu na dane dobro,

$\varepsilon \quad-\quad$ elastyczność cenowa popytu na dane dobro lub mieszana elastyczność cenowa popytu.

W specyfikacji powyższej liczba ludności oraz zmiany dochodu są kategoriami egzogenicznymi, zaś ceny mają charakter endogeniczny. Sporym wyzwaniem jest tu precyzyjne uwzględnienie prawa Engla, iż elastyczność dochodowa popytu maleje, gdy rosną dochody konsumentów.

Drugim wariantem oszacowania popytu w modelach PE jest jego wyrażenie w kaloriach, która to wielkość staje się ograniczeniem w rozwiązaniu określonego problemu optymalizacyjnego. Równanie popytu ma wówczas następującą postać:

$$
D_{r, t}=\operatorname{Pop}_{r, t} F\left(\frac{Y_{r, t}}{\operatorname{Pop}_{r, t}}, t\right)=\operatorname{Pop}_{r, t} \alpha(t)\left(\frac{Y_{r, t}}{\operatorname{Pop}_{r, t}}\right)^{\beta(t)}
$$

Parametry $\alpha(t)$ i $\beta(t)$ są szacowane w procedurze ekonometrycznej w oparciu o dane panelowe dotyczące historycznego popytu i dochodów per capita. W tym podejściu popyt na produkty zwierzęce (LS) trzeba jednak wyznaczyć oddzielnie. Często w tym momencie korzysta się z propozycji FAO, którą oddaje kolejne równanie:

$$
L S=G\left(\frac{Y_{r, t}}{\text { Pop }_{r, t}}, t\right)=\rho(t) \sqrt{\frac{Y_{r, t}}{P o p_{r, t}}} e^{-\frac{Y_{r, t}}{\text { Pop }_{r, t}} \sigma(t)}
$$

Parametry $p(t)$ oraz $\delta(t)$ także szacowane są ekonometrycznie. Człon $\rho(t) \sqrt{\frac{Y_{r, t}}{\text { Pop }_{r, t}}}$ rośnie w krajach o niskich dochodach per capita, ale wykazuje stagnację, gdy dochody są wysokie. Z kolei człon $e^{-\frac{Y_{r, t}}{P o p_{r, t}} \delta(t)}$ zbliża się do zera w przypadku bardzo wysokich dochodów per capita. Trzeba wyraźnie podkreślić, że podejście drugie nie zawiera cen produktów rolniczych, nie nadaje się więc do analizy szoków podażowych i klimatycznych oraz produkcji bioenergii.

Popyt rolno-żywnościowy w modelach CGE odwołuje się do koncepcji użyteczności oraz kategorii ograniczeń budżetowych gospodarstw domowych. 
Od razu pojawia się tu wyzwanie, które polega na możliwie precyzyjnym odzwierciedleniu w nich faktu empirycznego, iż w miarę wzrostu dochodów per capita maleje udział wydatków żywnościowych w budżetach reprezentatywnych gospodarstw. Jako pierwsze rozwiązanie pojawił się liniowy system wydatków (ang. the Linear Expenditure System, LES), w którym funkcja użyteczności ma poniższą postać:

$$
u_{r, t}=\prod_{c}\left(d_{r, c, t}-\gamma_{r, c, t}\right)^{\mu_{r, c, t}}
$$

gdzie:

u - użyteczność,

$d \quad$ - konsumpcja per capita,

$\mu, \gamma$ - szacowane parametry, przy czym ten drugi określa się jako minimalny poziom konsumpcji.

Maksymalizując następnie funkcję $u$ względem danego ograniczenia budżetowego, uzyskuje się następującą funkcję popytu:

$$
\begin{gathered}
d_{r, c, t}=\gamma_{r, c, t}+\frac{\mu_{r, c, t}}{P_{r, c, t}}\left[y_{r, t}-\sum_{c^{\prime}} P_{r, c^{\prime}, t} \gamma_{r, c^{\prime}, t}\right] \\
\Downarrow \\
D_{r, c, t}=\operatorname{Pop}_{r, t} \gamma_{r, c, t}+\frac{\mu_{r, c . t}}{P_{r, c, t}}\left[Y_{r, t}-\operatorname{Pop}_{r, t} \sum_{c^{\prime}} P_{r, c^{\prime}, t} \gamma_{r, c^{\prime}, t}\right]
\end{gathered}
$$

gdzie:

y $\quad$ - wydatki na dobra i usługi per capita.

Jak z powyższego wynika, popyt jest tu sumą minimum konsumpcji $(\gamma)$ oraz pozostałości wydatków po jego pokryciu $(\mu)$. Resztę tę określa się jako dochód dodatkowy. Niestety, LES niekiedy pozostaje w sprzeczności z obserwacjami empirycznymi i cechuje się niewielkimi możliwościami operowania zróżnicowanymi elastycznościami cenowymi popytu. Gdy $\gamma$ jest wartością stałą, system ten zbiega do funkcji Cobba-Douglasa.

Alternatywnym rozwiązaniem jest wykorzystanie zagnieżdżonej funkcji CES, a w istocie kombinacji poniższych funkcji użyteczności:

$$
u_{r, i, t}=\left(\sum_{j} A_{r, i, j} \cdot d_{r, i, j, t}^{\rho i}\right)
$$


gdzie:

$u_{r, i, t} \quad$ - użyteczność związana z konsumpcją pewnej grupy (wiązki) produktów żywnościowych $i$,

$d_{r, i, j, t}-$ popyt na produkt $j \mathrm{w}$ grupie $i$,

$A_{r, i, j} \quad$ - parametry kalibracji funkcji.

Elastyczność cenowa popytu określona jest teraz przez elastyczność substytucji między dobrami żywnościowymi i nieżywnościowymi. W ten sposób odzwierciedlenie znajdują preferencje konsumentów oraz zmiany diety wraz ze wzrostem dochodów reprezentatywnych gospodarstw domowych.

Popyt rolno-żywnościowy można modelować też przy użyciu stałych różnic elastyczności (ang. the Constatnt Differences in Elasticies, CDE) funkcji użyteczności. Praktyczną procedurę zazwyczaj rozpoczyna się od zdefiniowania pośredniej funkcji użyteczności, a funkcję popytu wyraża kolejna formuła:

$$
d_{r, c, t,}=\frac{\alpha_{r, c, t} b_{r, c, t} u_{r, t}^{e_{r, c} b_{r, c, t}}\left(\frac{P_{r, c, t}}{y_{r, t}}\right)^{b_{r, c, t}-1}}{\sum_{c^{\prime}} \alpha_{r, c^{\prime}, t} b_{r, c^{\prime}, t} u_{r, t}^{e_{r, c, t} b_{r, c^{\prime}, t}}\left(\frac{P_{r, c^{\prime}, t}}{y_{r, t}}\right)^{b_{r, c^{\prime} t}}}
$$

gdzie:

$b$ - efekty substytucyjne między elastycznością cenową danego dobra a elastycznością cenową mieszaną,

$e$ - parametr odzwierciedlający reakcje popytu na zmianę dochodu.

Podejście to daje wprawdzie bardziej realistyczne oszacowania elastyczności cenowej popytu niż LES, ale niekiedy elastyczności dochodowe dla końcowego roku modelowania są bliskie wartościom z roku początkowego.

$\mathrm{W}$ modelowaniu popytu zdecydowanie rzadziej stosuje się jeszcze inne metody jego ujmowania. Nawiązują one bezpośrednio wciąż jednak do funkcji użyteczności, jak ma to miejsce np. w przypadku rzędu tej funkcji (ang. rank number) oraz systemu bezpośrednio uwikłanego popytu addytywnego (ang. An Implicit Directly Additive Demand System, AIDADS), zbieżnego bezpośrednio w określonych warunkach do LES albo w sposób pośredni. Do tego drugiego podejścia zalicza się przede wszystkim funkcję translogarytmiczną oraz jej pochodne w postaci prawie idealnego systemu popytu (ang. the Almost Ideal Demand System, AIDS) i w postaci funkcjonalnej, zawierającej człon kwadratowy w części opisującej poziom dochodu per capita. Ta ostatnia pozwala płynnie przejść do trzeciego rzędu funkcji użyteczności. Wciąż poszukuje się jednak 
nowych ujęć, które precyzyjniej oddawać będą ewolucję elastyczności cenowych i dochodowych popytu, a więc w istocie zmiany zachowań konsumentów, ich preferencji i diety dla możliwie szerokiej rozpiętości dochodów per capita. Bardziej pożądane własności dynamiczne funkcji użyteczności są konieczne, by można było okresowo rekalibrować modele CGE, jeśli chce się trafnie prognozować popyt w długim horyzoncie czasu, a z drugiej strony precyzyjnie oddawać stale komplikujące się zależności w globalnych łańcuchach dostaw produktów rolno-żywnościowych i w łańcuchach tworzenia w nich wartości dodanej.

$\mathrm{H}$. Valin et al. dokonali analizy porównawczej projekcji globalnego popytu rolno-żywnościowego w latach 2005-2050, a punktem odniesienia były wyniki uzyskane przez FAO (Alexandratos N., Bruinsma J., 2012). A oto główne wnioski:

1. W scenariuszu pośrednim, w którym w roku 2050 liczba mieszkańców świata wyniesie ok. 9,2 mld a przeciętny globalny dochód per capita się podwoi (z 6700 do 16000 USD), średni dla wszystkich modeli wzrost popytu rolno-żywnościowego ma wynieść ok. 74\%. Dla porównania można podać, że szacunek FAO nieco przekraczał 54\%. Także rozrzut wyników podawanych przez Valina et al., zawierający się między 62 a 98\%, przewyższa ocenę twórców modeli z FAO. Rozbieżność ta wynika przede wszystkim z tego, że Valin et al. założyli o 50\% wyższy poziom dochodu per capita w 2050 roku, który ma nastąpić głównie w Chinach i Indiach. Trzeba od razu dodać, że w niektórych modelach efekty dochodowe wzrostu popytu wzmacniane były lub redukowane przez efekty cenowe. Średni wynik dla produktów roślinnych, wynoszący ok. $+69 \%$, był ponownie wyższy od uzyskanego w FAO $(+50 \%)$, a przedział zmienności wahał się między +55 a $+97 \%$. To samo występowało w przypadku produktów zwierzęcych (średnio $+103 \%$ dla 10 modeli oraz $+76 \%$ dla FAO), jednak rozpiętość estymacji była największa (między $+61 \%$ a $+242 \%$ ).

2. W drugim scenariuszu socjoekonomicznym przyjęto, że liczba ludności w roku 2050 wyniesie ok. 10,2 mld, z największym przyrostem naturalnym w Afryce, Indiach i Azji Południowo-Wschodniej, ale globalny PKB będzie równy tylko ok. $2 / 3$ poziomu ze scenariusza pierwszego. Największy regres produktu (PKB) i dochodu per capita miałby przy tym nastąpić w Chinach (spadek o 46\%), Indiach (-50\%) oraz w Afryce Subsaharyjskiej (-52\%). W grupie krajów rozwiniętych (OECD oraz WNP) średnio łączna konsumpcja spada o $14 \% \mathrm{w}$ stosunku do scenariusza pierwszego, gdyż elastyczności cenowe i dochodowe popytu są w nich niższe, ale w jeszcze większym stopniu przyczyni się do tego zmniejszenie w nich liczby ludności. Z kolei, w krajach rozwijających się średnio może nieco wzrosnąć popyt na produkty roślinne, głównie za sprawą wciąż powiększającej się populacji, ale sporadycznie dotyczyć to będzie także produktów zwierzęcych, które odznaczają się w nich wyższymi elastycznościami dochodowymi popytu. Oszacowania 
są przy tym bardzo niepewne co do faktycznego kształtowania się konsumpcji mięsa nieprzeżuwaczy w Chianch i Indiach oraz produktów mleczarskich w tym drugim kraju.

3. Reakcje produkcji rolniczej, cen produktów rolnych, dochodów konsumentów oraz popytu rolno-żywnościowego na zmianę klimatu, którą wyrażono jako średnią z czterech scenariuszy, ale w sumie bardzo zbliżonej do najbardziej pesymistycznej wersji (koncentracja dwutlenku węgla rośnie z 370 ppm do 540 ppm), okazały się zaskakujące. Większość modeli wykazywała znaczną elastyczność cenową popytu. Problem polega tu jednak na tym, że z ich konstrukcji można było się tego spodziewać. Jednakże z drugiej strony, konsumpcja żywności, mierzona w kcal na osobę i dzień, w reakcji na szok klimatyczny dla średniej z dziesięciu porównywanych modeli spadłaby od 1,6 do $2,9 \%$. Nawet w modelach najbardziej czułych na powyższy szok spadek ten nie przekracza $6 \%$.

4. Tylko trzy modele dysponowały zadowalającymi rozwiązaniami odzwierciedlenia wpływu wytwarzania biopaliw drugiej generacji na produkcję rolniczą. W najgorszym razie można by z tego tytułu oczekiwać spadku konsumpcji kcal na osobę i dzień o 1,5\% (33 kcal).

\section{Dylematy związane z podażą produktów rolniczych}

Podaż pojedynczego produktu rolnego jest funkcją jego ceny, ceny innych produktów, cen czynników produkcji zużywanych w procesach wytwórczych, stanu technologii, celów oraz zachowań producentów rolnych (Koester U., 2010). Z kolei, podaż zagregowana rolnictwa, w układzie krajowym, regionalnym i globalnym, określana jest przez dostępność czynników produkcji, elastyczności ich substytucji, trajektorie zastosowania ziemi, efektywność procesu fotosyntezy, tempo i charakter zmian całkowitej i cząstkowej produktywności angażowanych zasobów oraz jej elastyczność cenową.

Globalna podaż produktów rolniczych, dzielona dodatkowo na kraje i ich grupy, regiony geograficzne, oraz prognozowana na odległe lata w przyszłości, modelowana jest także za pomocą narzędzi klasy CGE oraz PE. W tych ostatnich wydziela się ponadto modele proste (ang. ,shallow”) oraz „głęboko” ustrukturyzowane (ang. „,eep”). Wybór między CGE a PE jest sprawą trudną, ale rekomenduje się, by był on rozstrzygany na zasadzie empirycznej (Robinson S. et al., 2014). Jeśli zatem nadal rolnictwo jest ważnym działem gospodarki narodowej i jego funkcjonowanie ma duże znaczenie dla dalszych części łańcucha tworzenia wartości, występujące sprzężenia zwrotne między sektorem żywnościowym a resztą ekonomiki narodowej lepiej można ująć za pomocą modeli CGE, aczkolwiek podejmuje się różne próby, by do tych celów wykorzystać także modele „deep” PE. Trzeba bowiem przyznać, że te ostatnie precyzyjniej oddają więzi technologiczno-produkcyjne rządzące funkcjonowaniem rolnictwa. 
Technologie produkcji rolniczej w modelach CGE opisuje się za pomocą funkcji produkcji lub funkcji kosztów. W pierwszym przypadku zdecydowanie częściej stosuje się funkcję CES niż funkcję Cobba-Douglasa, co wynika m.in. z tego, że funkcja CES w określonych warunkach (jednostkowa elastyczności substytucji nakładów) przechodzi w funkcję C-D. Jeśli twórca modelu zdecyduje się na funkcję CES, postępowanie może rozpocząć od poniższej jej specyfikacji:

$$
X=F(H, Z)
$$

gdzie:

$H$ - areał ziemi w ha,

$X$ - zbiór jakiegoś ziemiopłodu,

Z - złożony zasób pozostałych czynników produkcji (Robinson S.et al., 2014).

Argument $Z$ odzwierciedla fakt wielopoziomowego zagnieżdżenia funkcji CES. Obejmuje on złożoną strukturę z co najmniej dwóch nakładów/czynników produkcji. W spotykanych w praktyce modelach CGE jako nakłady występują: ziemia, praca (dodatkowo dzielona na niewykwalifikowaną i wykwalifikowaną), kapitał, energia, zasoby naturalne, materiały ogółem (w tym zużywane w produkcji roślinnej), pasze. Już tylko ta okoliczność wskazuje na źródło znacznego zróżnicowania wyników modelowania podaży.

Funkcja produkcji, dana wzorem 8 , jest homogeniczna stopnia pierwszego względem $H$ i $Z$, a zatem odzwierciedla stałe korzyści skali. Aby dotrzeć do plonu z jednego hektara, można ją przekształcić w poniższy sposób:

$$
y=\frac{X}{H}=\frac{\partial F}{\partial Z}\left(\frac{Z}{H}\right)+\frac{\partial F}{\partial H}
$$

Najprostsze modele PE explicite operują areałem ziemi i plonami, abstrahują jednak od pozostałych czynników produkcji. Inaczej jest natomiast w modelach CGE, w których plony zależą od relatywnego znaczenia (udziału) poszczególnych czynników w produkcji oraz zmiany ich produktywności. Prowadzi nas to do zagadnienia elastyczności substytucji czynników produkcji. W przypadku ww. funkcji CES z dwoma czynnikami, zbiór określonego ziemiopłodu może być zapisany jeszcze inaczej:

$$
X=a\left[\delta Z^{-\rho}+(1-\delta) H^{-\rho}\right]^{-1 / \rho}
$$

gdzie:

$a, \delta, p$ - parametry, przy czym $\delta$ oznacza udział nakładów innych niż ziemia. 
Stąd elastyczność substytucji równa się:

$$
\sigma=\frac{1}{1+\rho}
$$

Mając funkcję produkcji CES i zakładając, że czynnik ziemi będzie wielkością stałą, można tak przekształcić powiązaną z nią funkcję kosztów zmiennych, by ostatecznie dojść do elastyczności podaży produkcji rolniczej względem ceny $(\varepsilon)$ :

$$
\varepsilon=\frac{\hat{X}}{\hat{P}}=\sigma\left[\frac{a^{\rho}}{1-\delta}\left(\frac{X}{H}\right)^{-\rho}-1\right]=\sigma\left[\frac{\delta}{1-\delta}\left(\frac{H}{Z}\right)^{\rho}\right]=\sigma\left[\frac{\delta}{1-\delta}\left(\frac{H}{Z}\right)^{\frac{1-\sigma}{\sigma}}\right]
$$

Jeśli następnie uprościmy sobie problem i przygotujemy dane wyjściowe do modelowania tak, aby $Z=H=1$, to $\delta \mathrm{i}(1-\delta)$ będą oznaczać udziały tych czynników w wartości produkcji rolniczej. Wówczas elastyczność podaży redukuje się do następującego wyrażenia:

$$
\varepsilon=\left(\frac{\delta}{1-\delta}\right) \sigma
$$

W funkcji produkcji Cobba-Douglasa elastyczność podaży może być wielkością stałą. Jeśli jednak rośnie udział ziemi (czynnika stałego) w wartości produkcji, elastyczność ta jednak maleje. Z kolei w funkcji CES elastyczność podaży reaguje na wartość ilorazu $H / Z$. Ten ostatni z reguły maleje wraz z upływem czasu. Gdy elastyczność substytucji jest mniejsza od jedności, elastyczność podaży będzie maleć, o ile spadać będzie też wartość stosunku $H / Z$. Jest to dominujące założenie w modelach CGE. Oznacza to, że elastyczność podaży powinna maleć, gdy gospodarka nadal będzie rozwijać się. Trzeba jeszcze dodać, że elastyczność podaży w obydwu rozważanych funkcjach produkcji reaguje również na udział czynnika stałego (ziemi) w całkowitych zwrotach (rentownościach, zyskach/dochodach) z sumy czynników produkcji lub w wartości dodanej. Gdy udział ten rośnie, podaż staje się bardziej nieelastyczna. Dodatkowo, w funkcji CES w miarę pogorszenia elastyczności substytucji maleje elastyczność podaży. To typowa sytuacja w rozwijającym się rolnictwie i gospodarce, tzn. dla takich warunków elastyczności podaży jest mniejsza od jedności. $\mathrm{W}$ bardziej zaawansowanych analizach należałoby tu jeszcze uwzględnić fakt, iż elastyczność podaży powinna być szacowana względem cen „netto”, a więc różnicy między ceną produktu rolniczego a kosztem nakładów pośrednich (materiałów) na jednostkę produktu ${ }^{3}$. Korekta ta może być pomijana jednak w rol-

\footnotetext{
${ }^{3}$ Tak rozumiana cena „netto” różni się zdecydowanie od spotykanej w ekonomii i rachunkowości, w których jest ona różnicą między ceną płaconą przez nabywcę (ceną brutto) a należnym podatkiem VAT.
} 
nictwie krajów słabiej rozwiniętych, w których mało korzysta się jeszcze z nakładów pośrednich.

W najprostszych modelach PE podaż produkcji rolniczej jest prezentowana explicite $\mathrm{w}$ powiązaniu $\mathrm{z}$ funkcjami areału ziemi, plonami i cenami produktów rolniczych oraz nakładów $\left(P_{j}\right)$. Opisuje to następująca trójczłonowa formuła:

$$
\begin{gathered}
X=y H, \\
y=\alpha \prod_{j} P_{j}^{\eta_{j}}, \\
H=\beta \prod_{j} P_{j}^{\mu_{j}},
\end{gathered}
$$

W powyższej specyfikacji przyjmuje się, że plony roślin rosną, gdy rosną ceny odpowiednich ziemiopłodów, a maleją, jeśli podwyższają się ceny nakładów (np. nawozów mineralnych) ${ }^{4}$. Areał ziemi zajmowany pod daną uprawę jest także funkcją cen produktów. Ogólna elastyczność podaży względem cen jest tu sumą parametrów $\eta$ i $\mu$ dla każdorazowo danego ich poziomu. Jest ona wielkością stałą, mniejszą od jedności (podaż nieelastyczna także) dla całego okresu modelowania. To bardzo rygorystyczne założenie. Może natomiast zmieniać się w modelach ,deep” PE, kiedy to wynika z symulacji. Wtedy to podaż ujmowana jest implicite jako wynik rozwiązania określonego problemu optymalizacyjnego.

Złożoną kwestią modelowania podaży produkcji rolniczej jest włączenie postępu technicznego. W prostych modelach PE odzwierciedla się to w postaci zmian trendów plonowania. Postęp techniczny egzogeniczny ujawnia się w ten sposób również w modelach typu ,deep”, jednak może mieć w nich także komponent endogeniczny, gdy chce się uwzględnić ceny nakładów lub dostępność ziemi. W modelach CGE z funkcją produkcji CES postęp powyższy wyrazić można natomiast $\mathrm{w}$ poniższy sposób:

$$
X=a\left[\delta\left(a_{z} Z\right)^{-\rho}+(1-\delta)\left(a_{H} H\right)^{-\rho}\right]^{-1 / \rho}
$$

gdzie:

$a-$,neutralna” całkowita produktywność czynników produkcji (ang. TFP),

$a_{Z}$ - postęp techniczny wyrażony w czynnikach produkcji innych niż ziemia,

$a_{H}$ - postęp techniczny wyrażony w czynniku ziemi.

\footnotetext{
${ }^{4}$ Należy zauważyć, że mamy tu do czynienia z sytuacją normalnej reakcji podaży na rosnącą cenę produktu rolniczego. W praktyce spotkać można jednak reakcję anormalną, nazywaną też odwróconą, tzn. rolnicy reagują wzrostem podaży na spadek ceny (Koester W., 2010).
} 
Wprawdzie poprawa wszystkich rodzajów produktywności prowadzi do wzrostu plonów, ale równocześnie mogą zmieniać się zwroty z poszczególnych czynników produkcji, co w konsekwencji ma wpływ na elastyczność podaży produkcji rolniczej oraz ceny produktów. Na to nakłada się jeszcze różne tempo zmian produktywności ziemi i pozostałych czynników produkcji, spośród których autorzy modeli na ogół bardzo eksponują wydajność pracy. (S. Robinson et al. operują nawet pojęciem efektywnej elastyczności podaży). We wdrożonych modelach CGE znaczenie mają ponadto kształtowanie się TFP w rolnictwie oraz pozostałych działach gospodarki narodowej, międzysektorowa mobilność czynników produkcji (odzwierciedla ona m.in. wrażliwość podaży produkcji rolniczej na zmiany popytu rolno-żywnościowego, co ujmuje się w funkcji dynamicznej stałej elastyczności transformacji [CET]), jak i relacje między ewolucją podaży ziemi w czasie a podażą produkcji.

Jest rzeczą bardzo interesującą, co badania empiryczne na ogół pokazują, że wzrost TFP w rolnictwie krajów wysoko rozwiniętych przewyższa jego tempo w przemyśle i usługach (Kets W., Lejour A., 2003). W krajach rozwijających się natomiast TFP $\mathrm{w}$ rolnictwie rósł szybciej niż w przemyśle. Problemem są z kolei nierozstrzygnięte zależności dla krajów średnio rozwiniętych (Martin W., Mitra D., 2001). W tym kontekście warto zwrócić uwagę, że w sektorze finansowym zmiany TFP były bardzo niskie, niekiedy wręcz następował spadek tego indeksu. To bardzo niekorzystne zjawisko, jeśli uwzględnimy postępującą $\mathrm{w}$ świecie finansjalizację, a więc nadmierny jego przerost w stosunku do PKB, która jest jednym z ważniejszych źródeł ostatniego kryzysu.

S. Robinson et al. przeprowadzili szeroko zakrojone badania porównawcze sześciu modeli CGE oraz czterech PE w zakresie symulacji globalnej podaży produkcji rolniczej w latach 2010-2050 (Robinson S. et al., 2014). Analizą objęto łącznie 15 produktów roślinnych i zwierzęcych. Ogólny wniosek jest oczywisty: wyniki są bardzo zróżnicowane i bez uzgodnienia podstawowych założeń modelowania sytuacja ta nadal będzie się utrzymywać. Gdyby jednak doszło do uzgodnień, modele PE nie muszą ustępować rozwiązaniom przygotowanym w ramach konwencji CGE.

Szczegółowej analizie ww. zespół badawczy poddał natomiast model MAGNET CGE, symulując skutki trzech scenariuszy:

1. Kontynuacji dotychczasowych trendów demograficznych i stopy wzrostu PKB.

2. Braku sektorowego zróżnicowania indeksu TFP.

3. Występowania tylko postępu technicznego wyrażonego w czynniku ziemi rolniczej.

Po przeprowadzeniu stosownych obliczeń okazało się, że:

- w scenariuszu nr 1 ceny produktów łącznie mogłyby obniżyć się w roku 2050 o $20 \%$, w drugim - tylko o ok. $2 \%$, ale w trzecim wzrosłyby o prawie $60 \%$. Paradoksalnie, pokazuje to, jak duże znaczenie dla procesów ceno- 
wych w rolnictwie ma postęp techniczny wyrażony w pracy, który w krajach wysoko rozwiniętych jest przeciętnie wyższy niż w usługach;

- łączna podaż analizowanych produktów w roku 2050 byłaby wyraźnie wyższa niż w roku 2010. Stopy wzrostu wyniosłyby odpowiednio: $54 \%$ (scenariusz 1), $50 \%$ (scenariusz 2) i 46\% (scenariusz 3). Dynamika wzrostu byłaby oczywiście wyższa, gdyby elastyczności cenowe i dochodowe popytu były większe, ale w rzeczywistości są niskie i pewnie takie pozostaną również w przyszłości. Zauważmy, iż estymowany wzrost podaży produkcji rolniczej wyraźnie nie nadąża za szacunkami globalnego popytu otrzymanymi przez Valina et al.

Warto w tym miejscu dodać, że pokazane powyżej ogromne zróżnicowanie wyników modelowania jest samo w sobie poważnym problemem, może wręcz bowiem kwestionować praktyczną przydatność takich prac. W związku z tym Międzynarodowe Stowarzyszenie Ekonomistów Rolnictwa (IAAE) zaprosiło przedstawicieli czołowych ośrodków zajmujących się modelowaniem, by spróbowali zharmonizować podstawowe założenia w nim przyjmowane. W efekcie przygotowano numer specjalny „Agricultural Economics” wydawnictwa IAAE, który ukazał się drukiem w roku 2014. Prace zespołu są kontynuowane, a kolejna publikacja ma być zaprezentowana w 2016 roku.

Ch. Miller i R.D. Robertson przeanalizowali prawdopodobny wpływ zmiany klimatu na plony 23 wybranych roślin w przekroju kontynentalnym (Müller Ch., Robertson R.D., 2014). Zdecydowali się przy tym na najbardziej pesymistyczny scenariusz, określany jako $\mathrm{RCP} 8.5$ (ang. the representative concentration pathway with a radiative forcing $8.5 \mathrm{~W} / \mathrm{m}^{2}$ ). Zgodnie $\mathrm{z}$ nim koncentracja $\mathrm{CO}_{2}$ w roku 2050 wyniesie prawdopodobnie 540 ppm, a w roku 2100 może osiągnąć nawet 935 ppm. Przyjęto, iż scenariusz powyższy włączony będzie do dwóch ogólnych modeli cyrkulacji (ang. a general circulation model, GCM), a więc modeli klimatycznych: HadGEM2-ES oraz IPSL-CMSA-LR. Drugim wymiarem modelowania były dwa globalne modele wzrostu roślin: DSSAT (ang. the Decision Support System for Agrotechnology Transfer) i LPJmL (ang. the Lund-Potsdam-Jena managed Land). Pierwszy bazuje na modelu pola rośliny uprawnej, drugi zaś jest modelem ekosystemowym. Jak z powyższego widać, rozważania Müllera i Robertsona mają w pierwszym rzędzie charakter modelowania zależności biofizycznych. Podstawowe uzyskane przez nich wyniki dla roku 2050 przedstawiono w tabeli 2. 
Tabela 2

Prawdopodobne globalne spadki plonów (w\%) wybranych pięciu roślin w roku 2050 spowodowane zmianą klimatu

\begin{tabular}{|c|c|c|c|c|}
\hline \multirow{4}{*}{ Roślina } & \multicolumn{4}{|c|}{ Modele klimatyczne } \\
\hline & \multicolumn{2}{|c|}{ HadGEM2-ES } & \multicolumn{2}{|c|}{ PSL-CMSA-LR } \\
\hline & \multicolumn{4}{|c|}{ Modele wzrostu rośliny: } \\
\hline & DSSAT & LPJmL & DSSAT & LPJmL \\
\hline Pszenica & -17.7 & -11.5 & -21.0 & -12.9 \\
\hline Kukurydza & -37.6 & -9.9 & 33.9 & -14.2 \\
\hline Ryż & -15.7 & -18.2 & -16.4 & -16.1 \\
\hline Soja & -16.8 & -20.4 & -13.0 & -29.8 \\
\hline Orzeszki ziemne & -20.9 & -24.3 & -18.4 & -21.2 \\
\hline
\end{tabular}

Uwaga: Oznaczenia modeli podano w tekście.

Źródło: Opracowanie własne na podstawie: Müller Ch., Robertson R.D.: Projecting future crop productivity for global economic modeling. Agricultural Economics, vol. 45, no. 1, 2014.

Jak wynika z tabeli, spadki plonów byłyby dotkliwe. Modelowanie, szczególnie w wymiarze przestrzennym, obciążone jest jednak dużą niepewnością, gdyż w trakcie agregacji danych mamy często do czynienia ze stromymi gradientami spowodowanymi przechodzeniem z niskich do wysokich oddziaływań zmiany klimatu. W rzeczywistości regres w plonowaniu nie musi być tak znaczący, Müller i Robertson pominęli bowiem możliwość tzw. nawożenia $\mathrm{CO}_{2}$, a więc pozytywnej reakcji niektórych roślin - zwłaszcza odznaczających się typem fotosyntezy C4 - na wyższe stężenie tego gazu w powietrzu oraz możliwe do wdrożenia w rolnictwie adaptacje do zmiany klimatycznej.

Zagadnieniem najbardziej elementarnym w rozważaniach nad uwarunkowaniami podaży produktów rolno-żywnościowych jest możliwość zwiększenia efektywności fotosyntezy. To nieuchronnie kieruje naszą uwagę w stronę inżynierii genetycznej, wspomaganej współcześnie zaawansowanymi technikami modelowania matematycznego oraz skokowo rosnącymi możliwościami obliczeniowymi komputerów. Jeśli chodzi zaś o samo modelowanie, to największe możliwości oferuje koncepcja wieloskalowa. W skrócie polega ona na równoczesnym analizowaniu poziomu cząsteczkowego (modelowanie molekularne), komórkowego (za pomocą zwyczajnych i cząstkowych równań różniczkowych), systemowego (modelowanie agentowe) i ekosystemowego (modelowanie metodą elementów skończonych).

Rosnące zainteresowanie zwiększeniem efektywności fotosyntezy bierze się z przyczyn powszechnie znanych, a więc z presji demograficznej i zmian diety towarzyszącej bogaceniu się oraz urbanizacji, ale też ze stopniowego wyczerpywania się potencjału plonotwórczego uprawianych teraz roślin i malejących 
nakładów finansowych na rolnicze badania i wdrożenia. Nie bez znaczenia jest i to, że efektywniejsza fotosynteza oznacza większą asymilację dwutlenku węgla, a to może nieco spowolnić zmianę klimatu. Wystarczy podać, że stężenie tego gazu cieplarnianego przed wybuchem rewolucji przemysłowej wynosiło blisko 280 ppm., obecnie jest wyższe niż 400 ppm., ale pod koniec bieżącego stulecia może przekraczać nawet 560 ppm. (Long P.S., Marshall-Colon A., Guang-Zhu, 2015). Scenariusz taki oznacza, że średnia temperatura naszej planety może wzrosnąć o $4-5^{\circ} \mathrm{C}$. Do niedawna uważano, że wielkością graniczną dla ludzkości jest wzrost rzędu co najwyżej $2^{\circ} \mathrm{C}$ (Leggevie C., Welzer H., 2012; Stern N., 2010).

Możliwości poprawy efektywności fotosyntezy zaprezentowane zostaną głównie na podstawie artykułu S.P. Longa et al. (Long et al., 2015). Zespół ten wychodzi od prostego równania:

$$
Y_{P}=Q \cdot \varepsilon_{i} \cdot \varepsilon_{c} \cdot \varepsilon_{p} \ldots
$$

gdzie:

$Y_{p}$ - plon potencjalnie możliwy do uzyskania z jednostki ziemi przy braku czynników stresogennych;

$Q$ - suma promieniowania słonecznego emitowanego w okresie wegetacji na jednostkę ziemi;

$\varepsilon_{i}$ - efektywność pochłaniania promieniowania słonecznego przez roślinę;

$\varepsilon_{c}$ - współczynnik konwersji energii promieniowania słonecznego w biomasę roślinną;

$\varepsilon_{p}$ - część biomasy zebrana w postaci plonu użytkowego - inaczej tzw. indeks zbioru (ang. the harvest index).

W wyniku pierwszej Zielonej Rewolucji udało się podwoić $\varepsilon_{p}$, który dziś dla pszenicy, ryżu i soi wynosi ok. 0,6 . Jednak ta sprawność, podobnie jak $\varepsilon_{i}$ oraz $\varepsilon_{c}$, obecnie zbliża się do górnej granicy. Szczególnym wyzwaniem jest tu niska rzeczywista wartość parametru $\varepsilon_{c}$. Dla roślin zaliczanych do typu fotosyntezy $\mathrm{C} 3$, a więc tych, które w fazie ciemnej (fragment cyklu Calvina-Bensona) tworzą przejściowo związek trójwęglowy (kwas 3 - fosfoglicerynowy), $\varepsilon_{c}$ wynosi ok. 0,02, czyli mniej więcej $1 / 5$ efektywności teoretycznej. Do typu C3 zalicza się m.in. pszenicę, ryż, soję i buraki cukrowe. Z kolei dla roślin o typie fotosyntezy C4 (m.in. kukurydza, proso, sorgo, trzcina cukrowa) w cyklu Hatcha-Slacka przejściowo pojawia się związek czterowęglowy: kwas szczawiooctowy. Rośliny te mają teoretyczny poziom $\varepsilon_{c}$ równy 0,13 , ale generalnie wykształciły mechanizmy anatomiczne i fizjologiczne pozwalające na zwiększenie w ich komórkach stężenia dwutlenku węgla, w porównaniu do roślin C3. Te ostatnie występują głównie w klimacie umiarkowanym, natomiast należące do typu C4 - przede wszystkim w klimacie zwrotnikowym, chociaż w Europie ten typ fotosyntezy spotyka się u ponad 100 roślin dziko rosnących. 
Problem z roślinami C3 polega jeszcze na tym, że w wyniku oddychania mogą tracić nawet $97 \%$ wody. Rośliny z fotosyntezą C4 są pod tym względem bardziej oszczędne, gdyż mogą zamykać aparaty szparkowe, dzięki czemu lepiej radzą sobie w warunkach suszy. Bardziej złożony jest natomiast wpływ stężenia dwutlenku węgla na asymilację, a więc i na sprawność fotosyntezy. Rośliny z typu C4 mają tzw. punkt kompensacji tego stężenia w pobliżu zera - wtedy ilość $\mathrm{CO}_{2}$ powstała $\mathrm{w}$ wyniku oddychania i fotooddychania równa się ilości asymilowanej. U roślin C3 punkt ten leży w przedziale 0,009-0,018\% (stężenie atmosferyczne to ok. $0,036 \%$ ). Natężenie fotosyntezy dla roślin C4 jest przy niskich stężeniach tego gazu wyższe niż dla roślin C3. Przy wartościach bliskich stężeniu optymalnemu te drugie uzyskują jednak pewną przewagę. Fakt ten wykorzystuje się do tzw. nawożenia roślin $\mathrm{CO}_{2}$ w uprawach szklarniowych. Nie wiadomo natomiast, jak nawożenie to mogłoby wyglądać w uprawach polowych. Nie można też zapominać, że stężenie $\mathrm{CO}_{2}$ powyżej $1 \%$ jest dla roślin toksyczne i prowadzi do zahamowania procesu fotosyntezy. W praktyce problem jest daleko bardziej skomplikowany, gdyż przebieg fotosyntezy zależy jeszcze od barwy i natężenia światła słonecznego, temperatury powietrza, stężenia tlenu i dostępności wody. Nie zmienia to w niczym ważności konkluzji generalnej Longa et al., iż istnieje wiele obiecujących możliwości zwiększenia efektywności fotosyntezy. Jak wynika z zestawienia 1, niektóre z nich są niemalże na ,wyciągnięcie ręki”, inne natomiast to dość odległa perspektywa. Nie mniej ważne jest to, że ten swoisty dekalog niezbędnych działań, wg Longa et al., oferuje jednocześnie potencjał do poprawy wykorzystania zasobów wody oraz mineralnych nawozów. Kwestie związane z wodą bardzo mocno podkreślają również m.in. A.M. Chaudhry i E.B. Barbier (Chaudhry M.A., Barbier B.E., 2013).

\section{Strategia radzenia sobie $\mathrm{z}$ wyzwaniami}

Przy założeniu, że w przyszłości bardzo prawdopodobna jest globalna nadwyżka popytu rolno-żywnościowego nad podażą surowców rolnych i żywnościowych, konieczne jest podjęcie i jednoczesne realizowanie działań skoncentrowanych na:

- ograniczeniu strat w całym łańcuchu żywnościowym oraz dostosowaniach do zmian klimatu, a także na redukcji gazów cieplarnianych przez rolnictwo i przeciwdziałaniu degradacji gleb i wód;

- zwiększeniu produktywności jednostki ziemi rolniczej przez wdrożenie postępu technicznego, najlepszych praktyk, rozsądne nawadnianie upraw oraz ewentualnie również ekspansję obszarową, jeśli odbywać się to będzie w sposób zrównoważony;

- zredukowaniu popytu poprzez zmiany diety, stymulowanie zachowań prozdrowotnych i minimalizację strat żywności w gospodarstwach domowych (Beddington J., 2012).

To strategia bez wątpienia najbardziej całościowa, ambitna, ale i najtrudniejsza. Jej istotę przedstawiono na rysunku 4. 


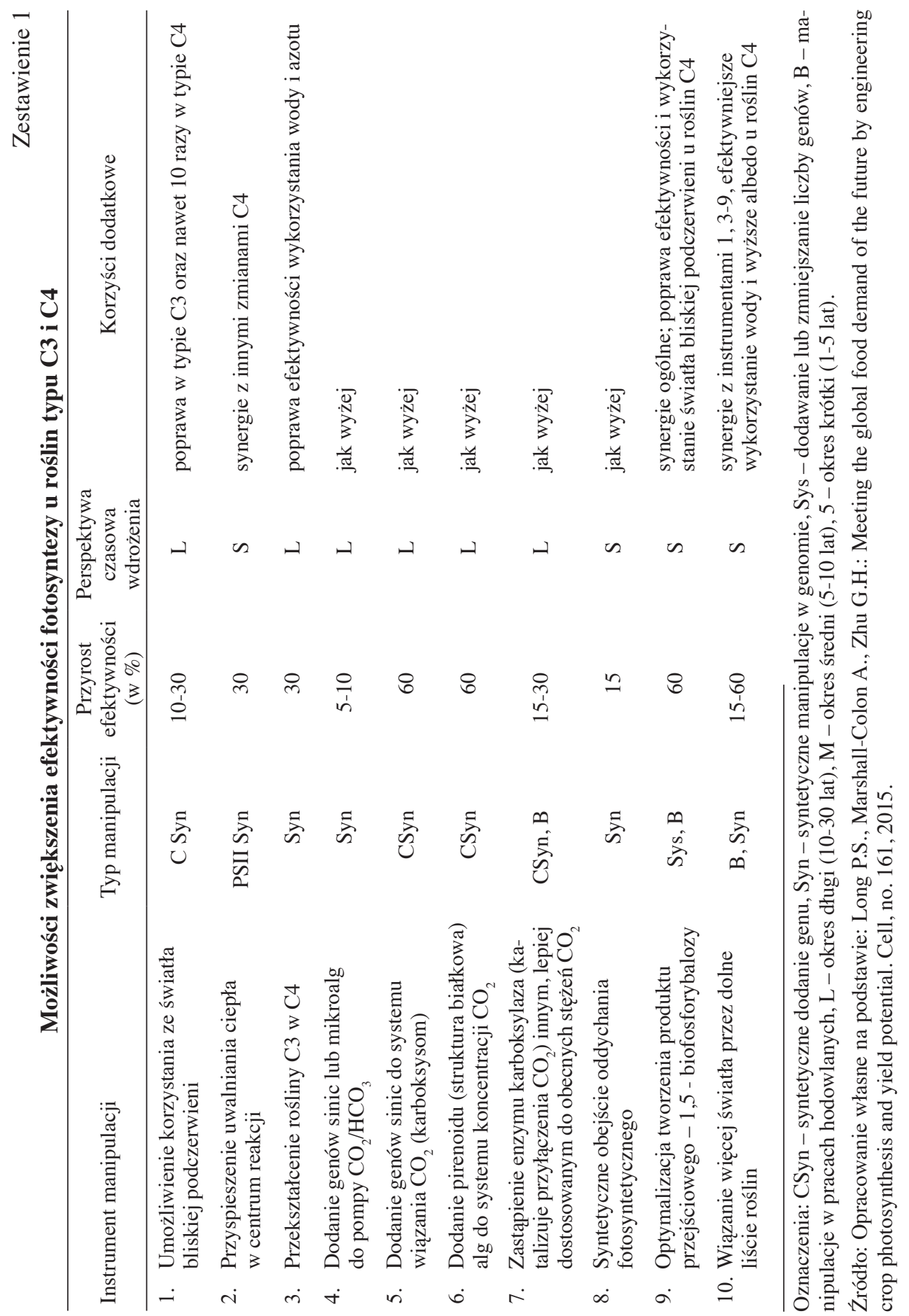


Drugą strategią, ściśle związaną jednak z wyżej scharakteryzowaną, ale przy tym już o charakterze cząstkowym, jest zamknięcie luki produktywności (ang. the closure of the yield gap). Pojęcie to zazwyczaj zawężane bywa do plonów roślin. Oznacza wtedy różnicę między ich poziomem maksymalnie osiąganym a rzeczywiście uzyskiwanym $\mathrm{w}$ danym regionie geograficznym (Beddington J., 2012; Godfray J.Ch.H. et al., 2010; Godfray J.Ch.H., Garnet T., 2014). Nie ma natomiast przeszkód, by lukę tę stosować również w przypadku wydajności jednostkowych zwierząt. Dalej jednak rozważania ograniczono do plonów. Trzeba jednakże zwrócić uwagę, że poziom maksymalny plonów w żadnym razie nie jest tożsamy z potencjałem biologicznym danej uprawy. To paradoksalne, że na świecie równocześnie współwystępuje w jednych regionach nadmierne stosowanie nakładów w rolnictwie, w drugich natomiast odczuwa się ich niedobór. Samo tylko zmniejszenie tej globalnej nierównowagi po stronie nakładów przyczyniłoby się do zracjonalizowania fazy produkcji rolniczej. Pożądane byłoby także lepsze dopasowanie nakładów do wymagań roślin i zwierząt, precyzyjniejsze ich dozowanie, rozpowszechnienie recyklingu, uregulowanie stosunków wodnych, poprawa szeroko rozumianego zarządzania, w tym dotyczącego ryzyka. Według szacunków A.J. Foley'ego et al., gdyby w przypadku 16 podstawowych surowców rolnych udało się zbliżyć do $95 \%$ ich potencjału, można by w skali globu dodatkowo zwiększyć ich produkcję o 2,3 mld ton i dostarczyć w ten sposób $5 \times 10^{15} \mathrm{kcal}$ (Foley J.A. et al., 2011). Zamknięcie luki w 75\% dałoby przyrost biomasy roślinnej o $1,1 \mathrm{mld}$ ton i energii o $2,8 \times 10^{15} \mathrm{kcal}$.

Bardzo zaawansowane badania luki produktywności ziemi przeprowadzili również N.D. Mueller et al. (Mueller N.D. et al., 2012). Zespół ten analizą objął 17 roślin, które zajmowały ok. 76\% światowych gruntów uprawnych. Modelowanie wykonane zostało dla lat 1997-2003. Stwierdzono, iż klimat, stosowanie nawozów mineralnych oraz nawadnianie upraw wyjaśniają od 60 do $80 \%$ obserwowanej światowej zmienności plonów. Podstawowym problemem jest tu stworzenie systemu, w którym w jednych regionach świata powinno wzrosnąć nawożenie i powierzchnia gruntów nawadnianych, natomiast w innych intensywność stosowania tych czynników powinna zmaleć, bo już obecnie wykazuje niezrównoważenie i nieefektywność. Bez wątpienia rolnictwo precyzyjne, uproszczone systemy uprawy, postęp techniczno-biologiczny i orientacja na wielofunkcyjność dostępnej przestrzeni wspierać będą proces osiągania nowej równowagi, nie szkodząc przy tym przyrodzie. Dużą rolę do spełnienia mają też nawozy organiczne, potencjał gleb i stosowane praktyki zarządcze. Jednak tymi czynnikami Mueller et al. nie zajmowali się. Nie zmienia to w niczym bardzo spektakularnych wyników ich modelowania. Okazało się bowiem, że stuprocentowe zamknięcie luk produktywności mogłoby zwiększyć światową produkcję badanych ziemiopłodów o 45 do $70 \%$.

Gdyby natomiast udało się wyeliminować nadmierne stosowanie nawożenia mineralnego, zbiory kukurydzy, pszenicy i ryżu mogłyby wzrosnąć o ok. 30\%. Pozytywny wpływ na środowisko przyrodnicze takiej redukcji nawożenia NPK 
jest oczywisty. Trzeba jeszcze dodać, że Europa Wschodnia, obok Afryki Subsaharyjskiej, jest regionem świata, gdzie luki produktywności są największe.

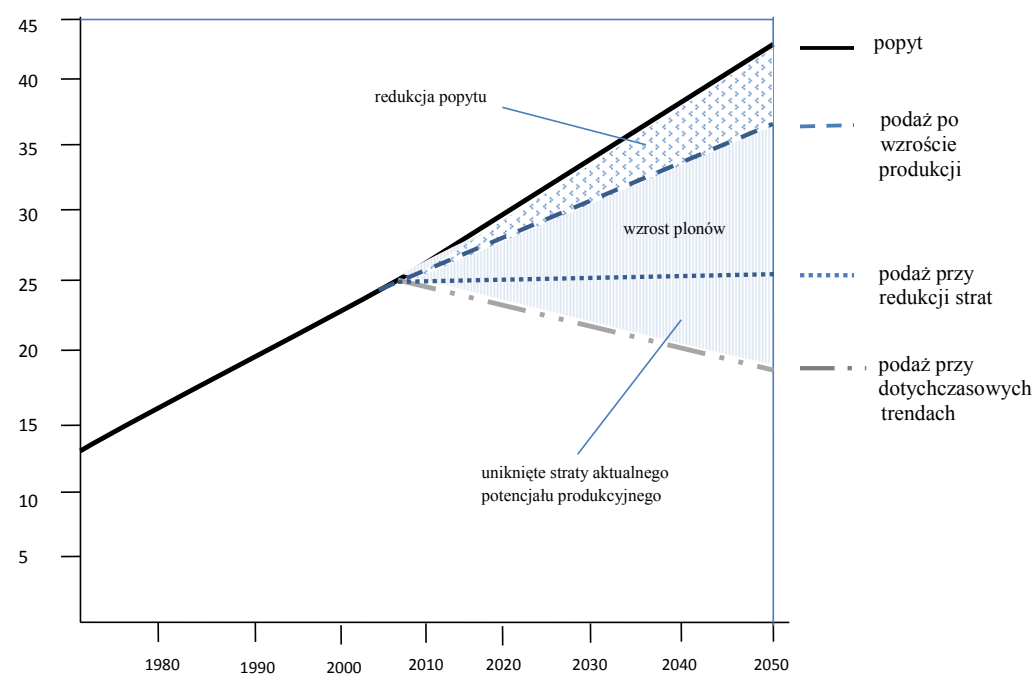

Rys. 4. Możliwości zrównoważenia popytu na żywność z jej podażą

Źródło: Opracowanie własne na podstawie: Beddington J.: Achieving food security in the face of climate change. Final report from the Commission on Sustainable Agriculture and Climate Change. CGAR, Denmark 2012.

Zredukowanie luk produktywności ziemi w pewnym stopniu przyczyni się także do ich złagodzenia, jeśli chodzi o czynnik pracy. Jak to pokazują D. Gollin et al., produktywność pracy poza rolnictwem bywa nawet cztery razy wyższa niż w rolnictwie drobnochłopskim (Gollin D. et al., 2012). Jak widać, pojęcie luki zostało tu rozszerzone, by uwypuklić więzi łączące rolnictwo z resztą gospodarki narodowej i możliwości poprawy ogólnej produktywności i dobrobytu zawarte w realokacji zasobów do najbardziej efektywnych ich zastosowań. Realokacja taka w samym rolnictwie zwiększyłaby efektywność skali, której to okoliczności nie uwzględnia się w modelowaniu zamknięcia luki produktywności ziemi. Z drugiej strony musimy wystrzegać się traktowania zmniejszania różnic w plonowaniu roślin jako prostego poprawiania dochodów drobnych rolników i łagodzenia biedy oraz ubóstwa na wsi. Klucz do rozwiązania tych problemów znajduje się przede wszystkim poza rolnictwem. Trzeba przypomnieć, że wciąż $\mathrm{w}$ wielu krajach afrykańskich $\mathrm{w}$ rolnictwie pracuje nawet połowa zatrudnionych, a w Etiopii i Burkina Faso wskaźnik ten dochodzi do 75\%.

Z zamykaniem luki produktywności bardzo ściśle wiąże się strategia zrównoważonej intensyfikacji. To nic innego niż wytworzenie większej ilości produkcji rolniczej z jednostki ziemi, przy równoczesnym zredukowaniu negatyw- 
nych następstw działalności rolniczej dla środowiska przyrodniczego, bez konieczności zajmowania nowych areałów na potrzeby rolnictwa (Franks R.J., 2014; Godfray J.Ch.H. et al., 2010; Godfray J.Ch.H., Garnet T., 2014). Główne założenia tej koncepcji przedstawiono na rysunku 5., gdzie jest gospodarstwo efektywne G położone na krzywej możliwości produkcyjnych (a production possibility frontier, PPF), która może przesuwać się w górę na skutek postępu technicznego, oraz obiekt $z$ - nieefektywny technicznie. Wszystkie jednostki znajdujące się na krzywej PPF mogą realizować strategie zrównoważonej intensyfikacji, gdy przemieści się ona w górę i w prawo. Gospodarstwo nieefektywne $z$ ma natomiast kilka trajektorii rozwoju, by stać się efektywnym. Przykładowo, może wybrać wariant a, tzn. podwyższyć plony przy stałej ilości dostarczanych usług środowiskowych. Może próbować także równocześnie poprawić produktywność i wolumen usług środowiskowych (opcje b lub c). Wariant d oznacza z kolei poprawienie tylko efektywności środowiskowej. (pytanie, czy jest to zrównoważona intensyfikacja?). Opcje e i f natomiast powinny być rozpatrywane łącznie jako przypadek, w którym do uprawy włącza się ziemię dotychczas nierolniczą. Taka kombinacja miałaby sens i mieściłaby się w szerokim ujęciu zrównoważonej intensyfikacji, gdyby wzrost produkcji współwystępował z dostarczaniem dodatkowych usług środowiskowych. Praktyczne znaczenie takiej sytuacji z pewnością jest mocno ograniczone, zwłaszcza w krajach o dużej gęstości zaludnienia. Jak z tego widać, najbardziej pożądane są warianty b i c.

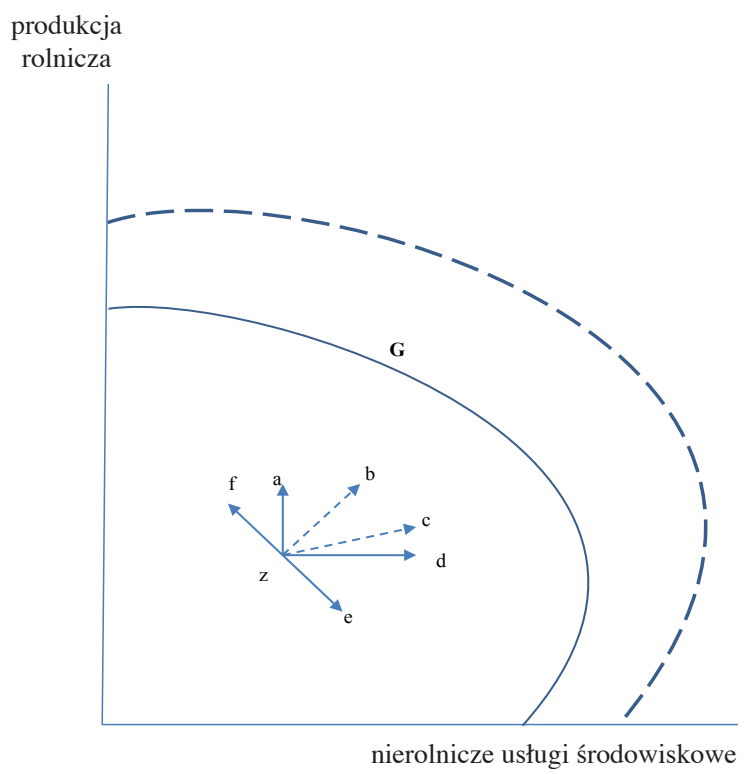

Rys. 5. Istota zrównoważonej intensyfikacji

Źródło: Opracowanie własne na podstawie.: Franks R.J.: Sustainable intensification: A UK perspective Food Policy. Nr 47, 2014. 
W rzeczywistości strategię powyższą można realizować w dwóch wariantach: jako „oszczędzającą ziemię”, a więc jej alokowanie do poszczególnych zastosowań odbywa się zgodnie z zasadą przewagi komparatywnej (ang. the land sparing model), oraz w formie ,wspólnego zasobu” (ang. the land sharing model). W tym drugim przypadku chodzi o traktowanie ziemi jako zasobu, który równocześnie ma służyć do dostarczania surowców rolnych i usług środowiskowych. Oczywiście, wariant ten jest wysoce zbieżny z unijną koncepcją zrównoważonego rolnictwa, ale zdecydowanie bardziej wymagający od strony odpowiedniego przełożenia go na politykę rolno-środowiskową. Wyzwaniem jest tu także przestrzenne zróżnicowanie instrumentarium powyższej polityki. Rozwiązanie to wymaga ponadto stworzenia spójnego systemu bodźców dla wszystkich interesariuszy, w tym także płatności rządowych za dostarczane usługi agrośrodowiskowe. Obydwa warianty zrównoważonej intensyfikacji zakładają także, że rolnicy zachowują się w sposób racjonalny, bardzo podobny do strategii zamykania luki produktywności.

Zrównoważona intensyfikacja może być składnikiem szerszej koncepcji, tzn. rolnictwa ochronnego lub konserwującego (ang. the conservation agriculture, CA). Zrównoważona intensyfikacja jako składnik rolnictwa ochronnego obejmuje wtedy trzy podstawowe elementy:

- minimalizację oddziaływania na glebę za pomocą mechanicznej uprawy;

- powiększanie i zachowanie substancji organicznej w glebie;

- dywersyfikację upraw

oraz cztery czynniki dodatkowe:

- użycie dobrze dostosowanych, wysoko plonujących odmian;

- poprawę zaopatrzenia roślin w składniki pokarmowe (głównie przez żyzność gleb);

- zintegrowane zarządzanie przed wystąpieniem szkodników;

- zintegrowane zarządzanie chorobami roślin, zachwaszczeniem i efektywnym gospodarowaniem wodą (Franks J., 2014; The Hague Conference..., 2010).

Trzeba od razu dodać, że CA jest poważnym wyzwaniem dla większości rolników. Jest to bowiem system „wiedzochłonny”, w którym rolnicy muszą wybierać między kombinacjami praktyk i twórczo dostosowywać je do lokalnych warunków (Kassam A. et al., 2011). Z drugiej natomiast strony koncepcja ta powinna być ważnym narzędziem adaptacji do zmiany klimatycznej. Prowadzi nas to wprost do ostatniej strategii - rolnictwa inteligentnego klimatycznie.

Jest to takie rolnictwo, które równocześnie w sposób zrównoważony poprawia swoją produktywność, staje się bardziej elastyczne (adaptacyjne), redukuje emisję gazów cieplarnianych, gwarantuje pożądany stopień bezpieczeństwa żywnościowego oraz wnosi pozytywny wkład w osiąganie nadrzędnych celów społeczno-ekonomicznych (The Hague Conference..., 2010). 
Dziesięć poniższych warunków składa się na taki typ rolnictwa:

1. We wszystkich krajach, ale przede wszystkim w rozwijających się, trzeba wdrożyć poważną transformację, aby zagwarantować bezpieczeństwo żywnościowe i dostosować się do zmiany klimatu.

2. Istnieją już efektywne praktyki adaptacji do zmiany klimatu i redukcji gazów cieplarnianych z sektora rolnego.

3. Potrzebna jest perspektywa ekosystemowa zorientowana na całą przestrzeń biofizyczną oraz skoordynowane wspólne działania ją chroniące.

4. Konieczne są poważne inwestycje w pozyskanie danych i tworzenie wiedzy, badania nad zachowaniem i nowymi odmianami i rasami zwierząt.

5. Pożądane jest wsparcie finansowe i instytucjonalne drobnych rolników.

6. Wzmocnienie potencjału instytucjonalnego w zakresie rozpowszechniania najlepszych praktyk dotyczących adaptacji do zmiany klimatycznej i redukcji emisji gazów cieplarnianych.

7. Niezbędna jest większa zgodność działań w zakresie rolnictwa, bezpieczeństwa żywnościowego i zmiany klimatu na poziomie krajowym, regionalnym i globalnym.

8. Dla sprostania wyzwaniu w postaci zapewnienia bezpieczeństwa żywnościowego i spowolnienia zmiany klimatu niewystarczające jest obecne i przewidywane finansowanie.

9. Niezbędne jest uzyskanie synergii między funduszami publicznymi i prywatnymi oraz wdrożenie autentycznych innowacji finansowych.

10. Potrzebne są instrumenty i mechanizmy finansowania w ramach tzw. szybkich ścieżek, a więc do radzenia sobie z nagłymi szokami, dobrze dostosowanymi do lokalnego rolnictwa (The Hague Conference..., 2010).

\section{Podsumowanie}

Przed rolnictwem światowym stoi poważne wyzwanie, jak zapewnić rosnącej liczbie ludności, prawdopodobnie przeciętnie bogacącej się, odpowiedni standard ilościowy i zdrowotny wyżywienia, obniżając (a przynajmniej nie zwiększając) presję na środowisko przyrodnicze i zmianę klimatu. Będzie rosła zatem konkurencja w zdobywaniu zasobów ziemi, wody, surowców energetycznych i mineralnych, niezbędnych do wytwarzania nawozów potasowych i fosforowych. Istnieje jednak kilka strategii sprostania powyższym wyzwaniom. Potrzebne są skoordynowane i konsekwentne działania, zarówno po stronie popytu (zmiany diety i wzorców konsumpcyjnych oraz redukcje strat), jak i podaży na rynkach rolno-żywnościowych. W szczególności trzeba starać się zamknąć istniejące obecnie luki produktywności, poprawić efektywność zastosowania wszystkich zasobów, inwestować w badania i wdrożenia rolnicze, zmniejszyć straty w całych łańcuchach żywnościowych. Działania powinno się podejmować przy tym równocześnie, i to na skalę globalną, co samo w sobie stwarza ogromny problem. Nasuwa się tu refleksja związana z negocjacjami klimatycz- 
nymi: niemal wszyscy zgadzają się, że przyjmując wielostronne porozumienie, łączny dobrobyt uległby maksymalizacji. Jednak pokusa ,jazdy na gapę” przeważa wśród wielu krajów, bo wciąż cele i efekty krótkookresowe oraz interesy narodowe mają priorytety.

Zawsze przewidywanie przyszłości jest ryzykowne i obarczone niepewnością. Okoliczność ta bardzo utrudnia m.in. zintegrowane modelowanie ekonomiczno-ekologiczno-klimatyczne tak potrzebne do konstruowania globalnej polityki rolno-żywnościowej. Nie ulega bowiem wątpliwości, że wybory dotyczące specyfikacji modeli, tj. ich formy funkcjonalnej i parametrów, elastyczności popytu i podaży, zestawu danych do kalibracji (i nieraz też okresowej rekalibracji), podejścia do agregacji i metody optymalizacji, generują poważne różnice wyników modelowania. Potrzebna jest zatem ścisła współpraca twórców modeli i symulacje parametrów, by sprostać tym wyzwaniom.

\section{Literatura:}

1. Alexandratos N., Bruinsma J.: World agriculture towards 2030/2050: The 2012 revision. ESA Working paper, no. 12-03, FAO, Rome 2012.

2. Beddington J.: Achieving food security in the face of climate change. Final report from the Commission on Sustainable Agriculture and Climate Change. CGAR, Denmark 2012.

3. Chaudhry M.A., Barbier B.E.: Water and growth in an agricultural economy. Agricultural Economics, vol. 44, no. 2, 2013, s. 175-189.

4. Foley J.A., Ramankutty K.A., Cassidy E.S., Gerber J.S., Johnston M., Mueller N.D., O’Connel C., Ray D.K., West P.C. Balzer C., Bennet E.M., Carpenter S.R., Hill J., Monfreda C., Polasky S., Rockström J., Sheehan J., Siebert S., Tilman D., Zaks D.P.M.: Solutions for cultivated planet. Nature, no. 478, 2011, s. 337-342.

5. Franks R.J.: Sustainable intensification: A UK perspective. Food Policy, nr 47, 2014, s. 71-80.

6. Godfray J.Ch.H., Beddington R.J., Crute R.I., Haddad L., Lawrence D., Muir F.J., Pretty J., Robinson S., Thomas M.S., Toulmin C.: Food security: The challenge of feeding 9 billion people. Science, no. 327, 2010, s. 812-818.

7. Godfray J.Ch.H., Garnet T.: Food security and sustainable intensification. Philosophical Transactions of the Royal Society B, nr 369, 2014, s. 2769-2778.

8. Gollin D., Lagakos D., Waugh M.E.: The agricultural productivity gap in developing countries. Working Papers. 11-14, New York University, 2012.

9. Kassam A., Friedrich R., Shaxson R., Reeves R., Pretty J., de Moraes Sá Carlos J.: Production systems for sustainable intensification. Technikfolgenabschätung, vol. 20, no. 2, 2011, s. 38-45.

10. Kets E., Lejour A.: Sectoral TFP developments in the OECD. CPB, Memorand 58, 2003.

11. Koester U.: Grundzüge der landwirtschaftlichen Marktlehre. 4. Auflage. Verlag Franz Vahlen, München 2010.

12. Kwasek M., Obiedzińska A.: Z badań nad rolnictwem społecznie zrównoważonym (26). Zrównoważone systemy rolnicze i zrównoważona dieta. Program Wieloletni 2011-2014, nr 119. IERiGŻ-PIB, Warszawa 2014. 
13. Leggevie C., Welzer H.: Koniec świata, jaki znaliśmy. Klimat, przyszłość i szanse demokracji. Wydawnictwo Krytyki Politycznej, Warszawa 2012.

14. Long P.S., Marshall-Colon A., Zhu G.H.: Meeting the global food demand of the future by engineering crop photosynthesis an yield potential. Cell, no. 161, 2015एणीया.

15. Lotze-Campen H., Müller Ch., Bondeau A., Rost S., Popp A., Lucht W.: Global food demand, productivity growth, and the scarcity of land and water resources: a spatially explicit mathematical programming approach. Agricultural Economics, vol. 39, no. 3, 2008, s. 325-338.

16. Martin W., Mitra D.: Productivity growth and convergence in agriculture and manufacturing. Economic Development and Culture Change, vol. 49, no. 2, 2001, s. 403-422.

17. Mueller D.N., Gerber S.J., Johnston M., Ray K.D., Ramankutty N., Foley A.J.: Closing yield gaps through nutrient and water managemant. Nature, 490, August 2012, s. 254-257.

18. Müller Ch., Robertson R.D.: Projecting future crop productivity for global economic model. Agricultural Economics, vol. 45, no. 1, 2014, s. 37-50.

19. Otsuka K.: Food insecurity, income inequality, and the changing comparative advantage in world agriculture. Agricultural Economics, vol. 44, 2013, s. 7-18.

20. Robinson S., van Meijl H., Willenbockel D., Valin H., Fujimori S., Masui T., Sands R., Wise M., Calvin K., Havlik P., Mason d'Croz D., Tabeau A., Kavallari A., Schmitz Ch., Dietrich J.P., von Lampe M.: Comparing supply-side specifications in models of global agriculture and the food system. Agricultural Economics, vol. 45, no. 1, 2014, s. 21-35.

21. Smith P.: Delivering food security without increasing pressure on land. Global Food Security, nr 2, 2013, s. 18-23.

22. Stern N.: Globalny ład. Wydawnictwo Krytyki Politycznej, Warszawa 2010.

23. Swinnen J., Riera O.: The global bioeconomy. Agricultural Economics, vol. 44, 2013, s. 1-5.

24. The Hague Conference on Agriculture Food Security and Climate Change. ClimatSmart Agriculture. Policies Practices and Financing for Food Security Adaptation and Mitigation, FAO, Rome 2010.

25. Valin H., Sands Ronald D., van der Mensbrugghe D., Nelson Gerald D., Ahammad H., Blanc E., Bodirsky B., Fujimori S., Hasegawa T., Havlik P., Heyhoe E., Kyle P., Mason-D'Croz D., Paltsev S., Rolinski S., Tabeau A., van Meijl H., von Lampe Martin, Willenbockel D.: The future of food demand: understanding differences in global economic models. Agricultural Economics, vol. 45, no. 1, 2014, s. 51-67.

26. Von Lampe M., Willenbockel D., Ahammad H., Blanc E., Cai Y., Calvin K., Fujimori S., Hasegawa T., Havlik P., Heyhoe E., Kyle P., Lotze-Campen H., Mason d'Croz D., Nelson Gerald D., Sands Ronald D., Schmitz Ch., Tabeau A., Valin H., van der Menbrugghe D., van Meijl H.: Why do global long-term scenarios for agriculture differ? An overview of the AgMIP Global Economic Model Intercomparison. Agricultural Economics, vol. 45, no. 1, 2014, s. 3-20.

27. Zilberman D., Kim E., Kirschmer S., Kaplan S., Reeves J.: Technology and the future bioeconomy. Agricultural Economics, vol. 44, 2013, s. 95-102. 
JACEK KULAWIK

Institute of Agricultural and Food Economics

- National Research

Warsaw

\title{
SELECTED PROBLEMS OF WORLD AGRICULTURE
}

\begin{abstract}
Summary
World agriculture faces a serious challenge: how to guarantee a relevant quantitative and health standard of food provision to a growing, and probably increasingly more affluent population, at the same time, reducing - or at least not increasing - the pressure on the environment and climate change. As a result, competition for land, freshwater, energy and mineral resources, necessary to produce potassium and phosphorus fertilisers, will be tougher.

However, there are some strategies to meet these challenges. Coordinated and consistent actions are necessary, both on the side of demand (changes in diet and consumption patterns, and reduction in food losses) and supply in agri-food markets. In particular, it is necessary to close the existing yield gaps, improve the efficiency in the use of all resources, invest in research and agricultural implementations, and reduce losses across the entire food chains. Individual actions should be taken simultaneously and on a global scale, which, in itself, poses a serious problem.

This instantly brings to mind the climate negotiations: almost everyone agrees that multilateral agreements would maximise the overall well-being, but the temptation to "get a free ride" prevails among many countries, as priorities continue to have short-term objectives and effects.
\end{abstract}

Key words: world agriculture, climate change, safe operating space, food security, agri-food demand, price elasticity, CGE and PE models, diet change, sustainable intensification

Zaakceptowano do druku - Accepted for print: 28.08.2015. 